\title{
Identifikasi Potensi dan Permasalahan Daya Dukung Lingkungan berdasarkan Aspek Daya Dukung Fisik, Daya Dukung Ekologis, dan Daya Dukung Sosial pada Pantai Baron, Kabupaten Gunungkidul, Yogyakarta
}

\author{
Anisa Hapsari Kusumastuti dan Adjie Pamungkas \\ Departemen Perencanaan Wilayah dan Kota, Fakultas Teknik Sipil dan Perencanaan \\ Institut Teknologi Sepuluh Nopember (ITS) \\ e-mail:adjie@urplan.its.ac.id
}

\begin{abstract}
Abstrak-Predikat Pantai Baron sebagai destinasi wisata bahari pada peringkat pertama dengan jumlah kunjungan wisata terbesar di Kabupaten Gunungkidul ternyata menimbulkan beberapa dampak buruk pada kualitas lingkungan di Pantai Baron yang jika dibiarkan akan memberikan dampak merugikan bagi obyek wisata itu sendiri. Penelitian ini bertujuan untuk mengidentifikasi potensi dan permasalahan daya dukung lingkungan berdasarkan aspek fisik, ekologis, dan sosial pada Pantai Baron yang ditempuh dengan teknik participatory mapping terhadap stakeholder yang berkaitan. Hasil eksplorasi potensi dan masalah pada aspek daya dukung fisik, ketersediaan infrastruktur yang sangat lengkap ternyata masih kurang dapat menampung kebutuhan wisatawan akan infrastruktur, terlebih pada hari libur. Persebaran infrastruktur wisata di Pantai Baron yang tidak terklaster menyebabkan kondisi ODTW terlihat semakin tidak teratur. Pada aspek daya dukung ekologis, penurunan kualitas lingkungan yang tercermin dari adanya pencemaran dari sampah-sampah wisatawan dan kegiatan TPI serta terjadinya abrasi di areal spantai yang membuat kapasitas tampung pengunjung menjadi berkurang. Sedangkan pada aspek daya dukung sosial, keramaian pada masing-masing spot atraksi wisata Pantai Baron ternyata menimbulkan kesan ketidakpuasan dari masing-masing narasumber karena tidak sesuai dengan jarak/radius ideal yang diinginkan.
\end{abstract}

Kata Kunci-Daya dukung lingkungan, daya dukung fisik, daya dukung ekologis, daya dukung sosial, pengembangan pariwisata bahari.

\section{PENDAHULUAN}

$\mathrm{D}$ AYA dukung lingkungan pada kegiatan wisata bahari didefinisikan sebagai jumlah maksimum orang yang dapat memanfaatkan suatu area tanpa menyebabkan perubahan lingkungan fisik dan kualitas pengalaman dari berekreasi tetap terjaga. [1]
Dalam lingkup Kepariwisataan Nasional, Provinsi Daerah Istimewa Yogyakarta menduduki peringkat kedua setelah Provinsi Bali. Salah satu kabupaten di Daerah Istimewa Yogyakarta (DIY) yang memiliki potensi kepariwisataan adalah Kabupaten Gunungkidul, dimana didominasi oleh jenis obyek wis ata alam pesisir, salah satunya adalah Pantai Baron. [2]

Pantai Baron merupakan salah satu pantai yang terletak di Desa Kemadang, Kecamatan Tanjungsari, Kabupaten Gunungkidul. Dalam kurun waktu lima tahun terakhir (20122016), jumlah wisatawan Pantai Baron meningkat dari 782.656 pengunjung menjadi 1.946 .555 pengunjung. Hal ini mengindikasikan telah terjadi peningkatan 248,71\% (Data kunjungan wisatawan Dinas Pariwisata Tahun 2012-2016), sehingga menjadikan pantai ini menempati peringkat pertama jumlah wisatawan terbanyak di Kabupaten Gunungkidul. [3]

Berbagai potensi wisata banyak ditemui di pantai ini. Potensi fisik adalah potensi yang berasal dari lingkungan buatan pantai, yaitu berupa obyek wis ata Pantai Baron yang pada taraf eksisting memiliki fasilitas yang tergolong lengkap. Sedangkan pada jenis potensi ekologis merupakan potensi yang berasal dari lingkungan alami pantai. Dimana Pantai Baron ini dikelilingi bukit-bukit kapur yang di atasnya terdapat jalan setapak dengan gardu pandang untuk dan menikmati keindahan laut, muara sungai bawah tanah, adanya spot berenang pada topografi landai, dan adanya spot tracking. Pantai Baron juga dilengkapi tempat pelelangan ikan yang biasa digunakan nelayan untuk menjual hasil tangkapan ikan. Keindahan dan berbagai macam potensi wisata yang dimiliki Pantai Baron tersebut ternyata menimbulkan beberapa permasalahan yang selanjutnya dibagi menjadi tiga aspek. Permasalahan pada aspek fisik adalah adanya genangan di seluruh areal parkir kawasan wisata karena ketidakteraturan kemiringan permukaan. Pada aspek ekologis, masalah yang muncul adalah penurunan kualitas lingkungan yang berasal dari lingkungan alami. Dimana yang terjadi pada Pantai Baron antara lain abrasi serta 
pencemaran di gisik pantai yang disebabkan oleh sampahsampah wisatawan. Masalah-masalah diatas ternyata memberikan dampak pada kepuasan pengunjung yang termasuk ke dalam aspek sosial. Adanya genangan di areal parkir tersebut menyebabkan wisatawan tidak nyaman dalam berwisata). [4]

Kemampuan pantai untuk mengakomodasi wisatawan dalam suatu Obyek Daya Tarik Wisata memiliki batasan toleransi. Upaya pemanfaatan dengan mempertimbangkan aspek daya dukung lingkungan diperlukan untuk menjamin eksistensi wisata pantai. Penelitian ini bermaksud untuk mengidentifikasi potensi dan permasalahan terkait dengan aspek daya dukung lingkungan pada Pantai Baron, Kabupaten Gunungkidul, Yogyakarta yang dibagi ke dalam tiga aspek, yaitu aspek daya dukung fisik, ekologis, dan sosial. [5]

\section{METODE PENELITIAN}

\section{A. Jenis dan Pendekatan Penelitian}

Jenis penelitian ini adalah penelitian kualitatif. Sedangkan pendekatan yang digunakan dalam penelitian ini adalah pendekatan positivistik

\section{B. Variabel Penelitian}

Variabel yang digunakan dalam penelitian ini antara lain perubahan garis pantai, pasang surut air laut, keadaan flora dan fauna di sekitar pantai, ketersediaan ruang terbuka publik dalam obyek wisata, sebaran dan jumlah flora dan fauna, kondisi fisik restoran, jumlah skala pelayanan restoran, jumlah skala pelayanan penyediaan air bersih, jenis penyediaan air bersih, kondisi fisik areal parkir, jumlah skala pelayanan areal parkir, jenis sistem pengelolaan air limbah, jumlah skala pelayanan air limbah, kondisi fisik kamarmandi umum, jumlah skala pelayanan kamar mandi umum, jumlah skala pelayanan fasilitas penyewaan pelampung, jumlah skala pelayanan sarana penyewaan tenda peneduh, jumlah skala pelayanan fasilitas pelayanan kesehatan, jumlah skala pelayanan fasilitas penanganan dan pengolahan hasil ikan tangkapan, dan jumlah skala pelayanan Gedung Tempat Pelelangan Ikan (TPI).

C. Mengidentifikasi Potensi dan Permasalahan yang Berkaitan dengan Daya Dukung Lingkungan di Pantai Baron

Participatory Mapping merupakan bentuk praktek nyata yang menggunakan pendekatan PRA/PLA dan kajian spasial keruangan secara partisipatif oleh stakeholders dalam menghasilkan dan mengatur spasial data dan menggunakan hasil informasi tersebut dalam mengambil keputusan, memudahkan proses berdialog antar komponen, mengefektifkan proses komunikasi serta mendukung advokasi dalam pelaksanaan. Pendekatan PRA/PLA merupakan pendekatan mengintegrasikan pendekatan partisipatif dengan metode pemetaan.

Tiga elemen yang dipilih sebagai stakeholders dalam kegiatan participatory mapping ini diantaranya adalah:
- Pihak pemerintah: Badan Perencanaan dan Pembangunan Daerah (Bappeda) Kabupaten Gunungkidul, Dinas Kebudayaan dan Pariwisata Kabupaten Gunungkidul, Dinas Kelautan dan Perikanan Kabupaten Gunungkidul, dan Kantor Pengendalian Lingkungan Hidup (Kapedal) Kabupaten Gunungkidul.

- Pihak swasta: Kelompok Nelayan Mina Samudera Pantai Baron, Paguyuban pelaku usaha rumah makan Pantai Baron.

- Pihak masyarakat: Kelompok Sadar Wis ata Pantai Baron.

Adapun beberapa tahapan yang perlu dilakukan dalam melakukan participatory mapping, diantaranya adalah:

- Tahap persiapan : Penyiapan data-data, baik spasial maupun non spasial yang digunakan dalam participatory mapping, misalnya peta yang digunakan sebagai peta dasar.

- Tahap Pelaksanaan : Stakeholders dapat melakukan pemetaan titik titik potensi dan permasalahan dengan media mapping, yaitu peta yang telah disediakan peneliti.

- Tahap Pengolahan pada GIS : Input data yang digunakan adalah data yang telah didapatkan melalui survey primer dan sekunder serta data-data yang telah dirangkum dari kegiatan participatory mapping dan selanjutnya diolah ke dalam software GIS.

\section{HASIL DAN PEMBAHASAN}

A. Identifikasi Potensi dan Permasalahan yang Berkaitan dengan Daya Dukung Lingkungan di Pantai Baron berdasarkan Aspek Daya Dukung Fisik. Daya Dukung Ekologis, dan Daya Dukung Sosial

Eksplorasi potensi dan permasalahan didasarkan atas indikator dan variabel yang sudah ditentukan pada bab sebelumnya. Eksplorasi potensi dan permasalahan didasarkan atas tiga aspek yangs sudah ditentukan, yaitu daya dukung fisik, daya dukung ekologis, dan daya dukung sosial. Setiap golongan selanjutnya telah dibedakan menjadi setiap aspek yang secara detail akan dieksplorasi.

Berdasarkan hal tersebut diatas, maka berikut ini adalah hasil analisis identifikasi fakta eksisting yang berkaitan dengan daya dukung lingkungan berdasarkan aspek fisik, ekologis, dan sosial yang selanjutnya akan digolongkan menjadi potensi dan permasalahan yang berkaitan dengan hal diatas:

\section{a. Daya Dukung Fisik}

1. Aspek Kondisi Pantai

Terdapat tiga aktivitas utama di Pantai Baron, yaitu Tempat Pelelangan Ikan (TPI), kegiatan wisata bahari, dan kegiatan wisata kuliner. Ketiga aktivitas tersebut masih berdiri sendirisendiri dan belum terintegrasikan satu sama lain sehingga menyebabkan masalah dari aktivitas satu dengan yang lainnya. Sejauh ini TPI Pantai Baron memang memiliki masalah lingkungan yaitu adanya bau dan sanitasi lingkungan yang tidak baik, sehingga mungkin pengunjung merasa kurang nyaman oleh bau yang ditimbulkan. Hal demikian yang 
dikemukakan oleh responden peneliti pada Dinas Kelautan dan Perikanan Kabupaten Gunungkidul.

Dari segi kondisi historis dua puluh tahun terakhir, jumlah wisatawan selalu mengalami peningkatan dari tahun ke tahun. Pada saat hari libur, terjadi peningkatan jumlah wisatawan daripada hari hari biasa. Hal demikian diungkapkan oleh salah satu responden yang merupakan representatif dari masyarakat, yaitu Kelompok Sadar W isata Pantai Baron pada saat kegiatan participatory mapping berlangsung.

Dari segi kebersihan lingkungan, salah satu narasumber yang berapa di Kantor Perlindungan Lingkungan Hidup mengatakan bahwa pengelolaan sampah semakin baik. Namun, seringkali terkendala pada pengangkutan sampah saat hari libur, dimana sampah-sampah sering menumpuk. Sedangkan dari segi padatnya aktivitas, lebih variatif sekarang.

\section{Aspek Ketersediaan Infrastruktur}

Ketersediaan infrastruktur di Pantai Baron sudah cukup lengkap. Namun yang disayangkan adalah adanya beberapa sarana dan prasarana yang secara fungsi masih belum dapat dimanfaatkan secara maksimal dan berkelanjutan. Hal demikian yang diungkapkan oleh beberapa stakeholders dari Dinas Pariwisata dan Bappeda Kabupaten Gunungkidul dengan pernyataannya sebagai berikut:

"Kondisi areal parkir sudah tidak mampu menampung kapasitas pada saat peak season, pengangkutan sampah kurang cepat saat hari libur, limbah-limbah ikan yang sering terlihat di belakang warung menyebabkan lingkungan terlihat kotor (1201-2017, Kepala Kepala Sub-Bidang Pertanahan dan Tata Ruang, Badan Perencanaan dan Pembangunan Daerah Kabupaten Gunungkidul)."

Aspek ketersediaan infrastruktur ini mengarah pada kondisi eksisting sarana dan prasarana yang menurut peneliti berkaitan dengan potensi dan permasalahan terkait dengan daya dukung lingkungan di wilayah studi, berikut penjelas annya:

\section{- Restoran}

Kondisinya dari warung-warung makan tergolong layak (bersifat permanen) dan dari sisi kapasitas masih memenuhi untuk jumlah pengunjung yang banyak. Namun yang dipermasalahkan adalah masalah lingkungan yang sering timbul karena limbah padat berupa sampah. Permasalahan lainnya adalah terkait dengan pedagang lapak makan yang ada di kawasan pasiran, dimana menyebabkan kesan semakin padat dan kumuh. Hal tersebut diatas dikemukakan oleh responden peneliti yang berada di Dinas Kelautan dan Perikanan dan Dinas Kebudayaan dan Pariwisata Kabupaten Gunungkidul.

\section{- Supply air bersih}

Pasokan air bersih didapatkan dari muara sungai bawah tanah yang mata airnya terdapat di Pantai Baron. Hal tersebut merupakan karakteristik karst di Kabupaten Gunungkidul.

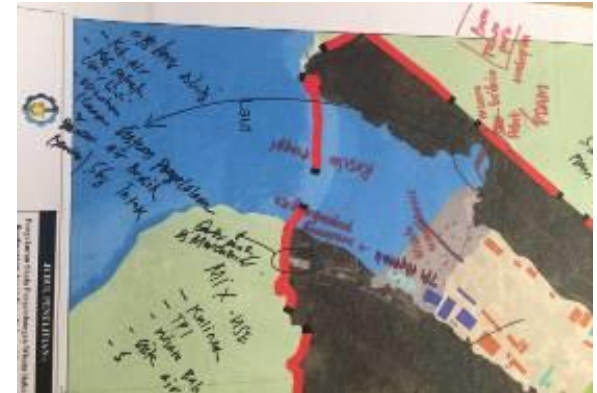

Gambar 1. Peta hasil sketsa Bappeda Kabupaten Gunungkidul dalam aspek supply air bersih

Debit muara sungai bawah tanah yang sangat melimpah, yaitu 10.800 liter/detik, sehingga dapat digunakan untuk memenuhi kegiatan obyek wisata dan rumah tangga sekitar Pantai Baron. Hal tersebut diatas dikemukakan responden peneiti yang berada di Bappeda Kabupaten Gunungkidul yang lebih lanjut diungkapkan melalui pernyataan sebagai berikut:

"Kondisi pasokan air bersih baik. Adanya water treatment yang mengolah dan memurnikan air bawah sungai menjadi steril dan kemudian disaluran ke rumah-rumah warga. Namun yang namanya air sungai bawah tanah pasti sudah tercampur dengan bakteri. (12-01-2017, Kepala Sub-Bidang Pertanahan dan Tata Ruang, Bappeda Kabupaten Gunungkidul)."

\section{- Areal parkir}

Walaupun ketersediaan areal parkir tergolong paling luas diantara pantai-pantai lain di Kabupaten Gunungkidul, saat hari libur kondisinya kurang dapat menampung jumlah kendaraan yang datang. Hal ini dikemukakan beberapa stakeholders, yaitu Kelompok Nelayan Mina Samudera Pantai Baron dan Kapedal Kabupaten Gunungkidul).

- Sistem pengelolaan limbah

Terdapat dua IPAL di Pantai Baron sebagai tempat penampungan limbah cair kegiatan kuliner berupa septictank. Masing-masing memiliki kapasitas 5.000 liter/detik. Pada taraf eksisting, kedua septictank tersebut masih kurang dapat menampung kebutuhan aktivitas wisatawan Sedangkan yang berkaitan dengan limbah kegiatan TPI, tidak terdapat tempat penampungan secara khusus (Kelompok Nelayan Mina Samudera dan Kelompok Sadar Wisata Pantai Baron).

\section{Aspek Keanekaragaman Hayati}

Keanekaragaman hayati di Pantai Baron tidak terlalu beragam seperti pantai lainnya di Kabupaten Gunungkidul. Terkait dengan tindak eksploitasi yang sumberdaya hayati di Pantai Baron, dahulu sering kali terjadi. Namun sejak ada peraturan baru, nelayan tidak lagi melakukan eksploitasi tersebut. Hal tersebut diatas dikemukakan oleh stakeholders didalam lingkup Kappedal Dinas Kebudayaan dan Pariwisata Kabupaten Gunungkidul.

b. Daya Dukung Ekologis 


\section{Aspek Atraksi Wisata yang Disediakan}

Seperti yang diungkapkan responden Kelompok Sadar Wisata Pantai Baron, dari beberapa macam atraksi wisata yang disediakan oleh Pantai Baron, atraksi wisata yang menjadi favorit pengunjung adalah berenang dan wisata kuliner.

\section{Aspek Kejadian Abrasi}

Pantai Baron mengalami abrasi dari tahun ke tahun. Pada tahun 2016 ini terjadi dua kali kejadian abrasi yang tergolong cukup parah yang mengakibatkan lapak wilayah pasiran terhempas ombak dan aktivitas kenelayanan berhenti beberapa hari. Hal ini menyebabkan penurunan pendapatan nelayan dan kegiatan penjualan di warung-warung menjadi sepi (Bappeda Kabupaten Gunungkidul).

\section{Aspek Penurunan Daya Dukung Lingkungan}

Indikasi penurunan daya dukung lingkungan diamati dari kualitas lingkungan yang tergambar dari kualitas sarana prasarana terkait persampahan.

Sarana dan prasarana persampahan belum berfungsi secara maksimal. Hal ini terlihat dari banyaknya sampah yang tersebar serta limbah-limbah padat bekas olahan ikan yang menyebabkan estetika lingkungan dan pantai menjadi kotor. Hal ini diungkapkan oleh responden dari Dinas Kebudayaan dan Pariwisata Kabupaten Gunungkidul melalui pernyataan sebagai berikut.

"Penumpukan sampah biasanya disebabkan oleh aktivitas wisatawan, TPI, dan warung-warung. Kemudian juga adanya limbah hasil dari aktivitas pantai yang tidak diolah menyebabkan penurunan kualitas lingkungan terjadi lebih cepat. (13-01-2017, Kepala Bidang Sarana dan Prasarana, Dinas Kebudayaan dan Pariwisata Kabupaten Gunungkidul)"

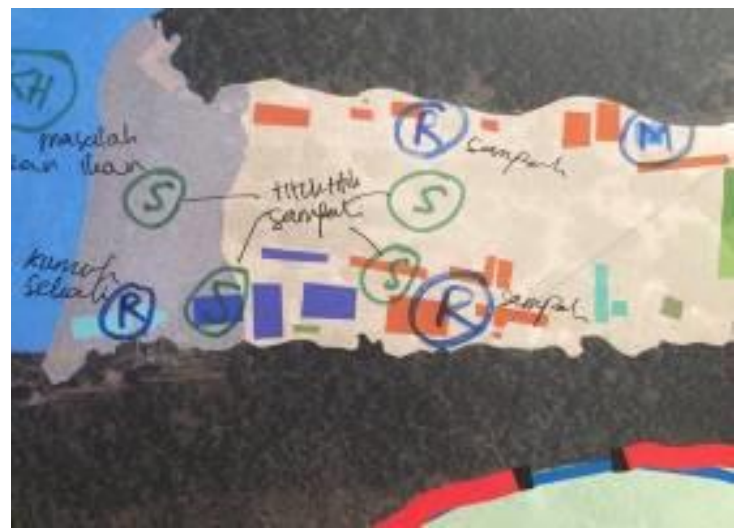

Gambar 2. Peta hasil sketsa Dinas Kebudayaan dan pariwisata dalam aspek penurunan daya dukung lingkungan

\section{c. Daya Dukung Sosial}

\section{Aspek Kesan terhadap Objek Wisata}

Pantai Baron adalah pantai yang unik, terdapat pasir, bukit, muara sungai, teluk, dan lain sebagainya. Dengan adanya fasilitas areal parkir yang luas, semakin meningkatkan keinginan wisatawan untuk berkunjung ke pantai ini.
Berdasarkan hasil participarory mapping yang telah dilakukan pada tahap sebelumnya, beberapa responden mengusulkan untuk perbaikan sistem zona wisata dengan integrasi dari setiap aktivitas sehingga dapat memecah kepadatan pada spot aktivitas favorit saat ini. Tentunya juga harus didukung infrastruktur yang memadai agar pengunjung merasa lebih puas dan betah dalam melakukan wisatanya di Pantai Baron. Hal ini diungkapkan salah satu responden penelitian Bappeda Kabupaten Gunungkidul melalui pernyataannya sebagai berikut.

"Diperlukan integrasi dari setiap aktivitas sehingga dapat memecah kepadatan pada spot aktivitas favorit saat in yang tentunya didukung infrastruktur yang memadai agar pengunjung merasa lebih puas dan betah dalam melakukan wisatanya di Pantai Baron (12-01-2017, Kepala Sub-Bidang Pertanahan dan Tata Ruang, Bappeda Kabupaten Gunungkidul)."

Lebih lanjut diungkapkan responden lain terkait dengan perlunya dilakukan pembagian ruang antara aktivitas berenang dan menikmati keindahan laut, mengingat zona untuk aktivitas ini bercampur dengan tumpukan parkiran perahu nelayan. Pada tahap akhirnya, diperlukan penambahan atraksi baru utnuk memecah kepadatan akan atraksi wisata favorit pengunjung saat ini, misalnya adalah wisata olahraga flying fox.

\section{Aspek Keidealan Lokasi}

Kondisi pada saat akhir pekan dan hari libur tertentu yang ramai pengunjung menyebabkan pantai ini tidak ideal lagi untuk suatu kunjungan wisata. Kaitannya dengan keidealan lokasi, berdasarkan pernyataan responden penelitian dalam participatory mapping yang telah dilakukan sebelumnya, jarak/radius ideal adalah 3-5 meter untuk atraksi wisata berenang, sedangkan untuk duduk santai dan rekreasi pantai (TPI) berkisar antara 1-2 meter. Hal ini diungkapkan oleh responden penelitian sebagai berikut.

"View of Clearance seharusnya bebas ke arah laut. Kondisi yang ada saat ini adalah sudah tidak nyaman. Terlebih apabila saat high season. Idealnya ya 5 meter (dimana hal ini dari sisi kebutuhan infrastruktur dan keluasaan wisatawan terpenuhi). Untuk yang lainnya saya kira 2 meter saja sudah cukup. (13-01-2017, Kepala Bidang Pengendalian dan Perlindungan Lingkungan Hidup, Kapedal Kabupaten Gunungkidul)." 


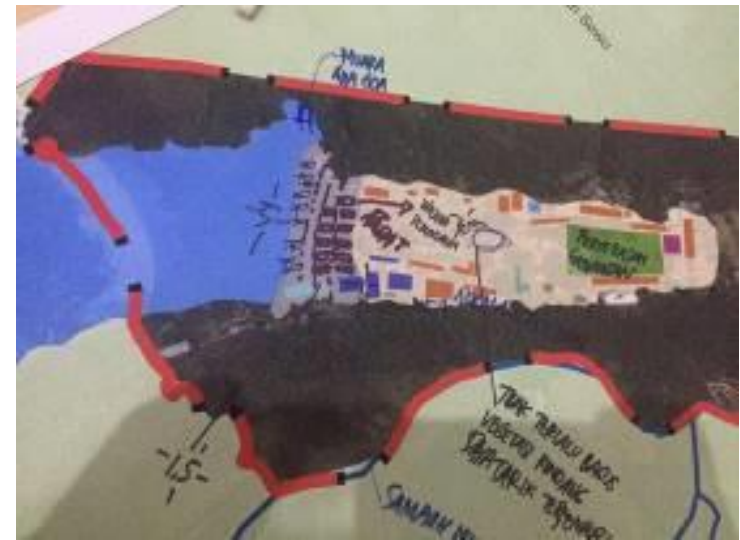

Gambar 3. Peta hasil sketsa Kappedal Kabupaten Gunungkidul pada aspek kesan terhadap obyek wisata dan keidealan lokasi

\section{KESIMPULAN}

Berikut ini adalah kesimpulan dari identifikasi potensi dan permasalahan terkait dengan aspek daya dukung lingkungan yang melingkupi aspek daya dukung fisik, ekologis, dan sosial:

- Pada aspek daya dukung fisik, potensi ketersediaan infrastruktur yang sangat lengkap ternyata masih kurang menampung kebutuhan wisatawan akan infrastruktur tersebut, terlebih pada hari libur. Persebaran infrastruktur wisata di Pantai Baron yang tidak terklaster menyebabkan kondisi ODTW semakin tidak teratur.

- Pada aspek daya dukung ekologis, terjadi penurunan kualitas lingkungan yang tercermin dari pencemaran sampah wisatawan dan kegiatan TPI serta terjadinya abrasi di areal pantai yang membuat kapasitas tampung pengunjung berkurang. Beberapa stakeholders mengusulkan adanya kegiatan pengolahan sampah untuk dijadikan produk bernilai guna.

- Pada aspek daya dukung sosial, keramaian setiap spot atraksi wisata Pantai Baron menimbulkan kesan ketidakpuasan narasumber karena tidak sesuai dengan radius ideal. Beberapa stakeholders mengusulkan adanya pemanfaatan atraksi wisata yang masih tergolong minat khusus dan penambahan atraksi wisata baru.

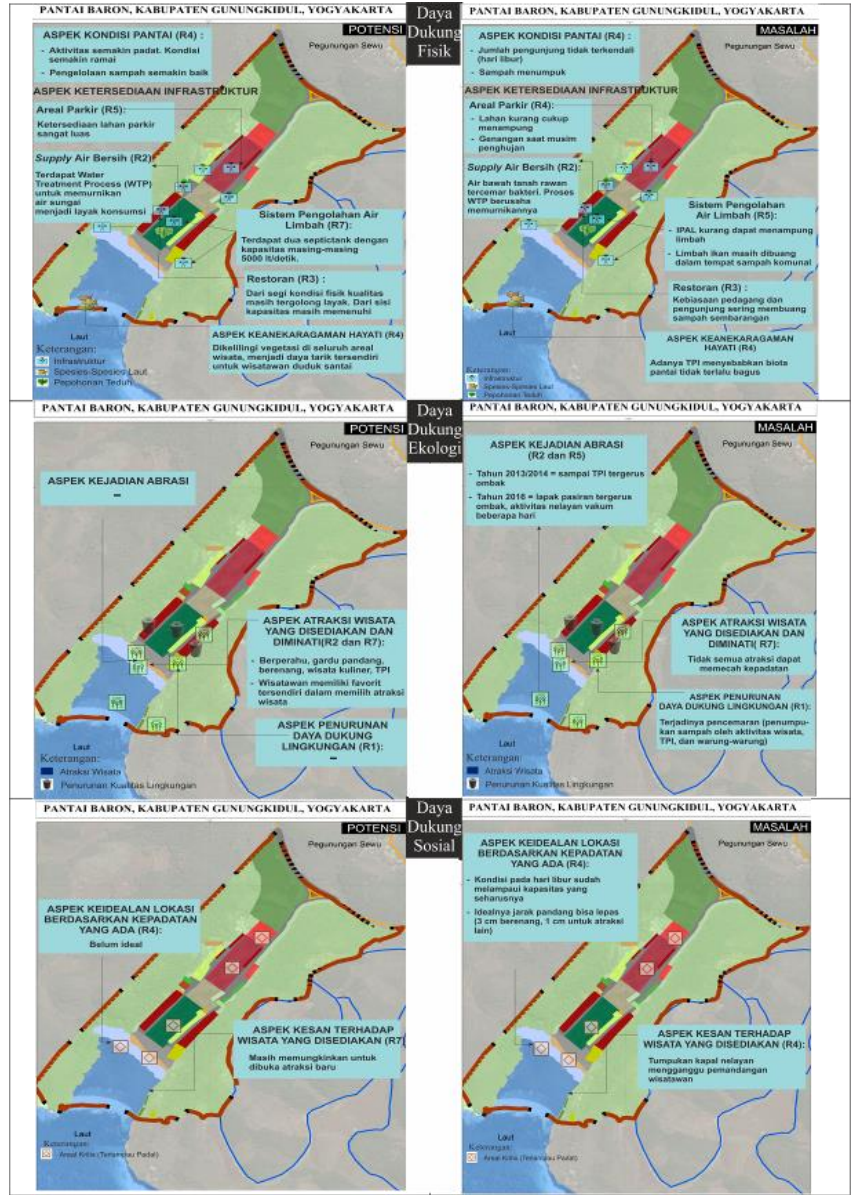

Gambar 4. Peta eksplorasi potensi dan masalah pada aspek daya dukung fisik, daya dukung ekologis, dan daya dukung social

\section{DAFTAR PUSTAKA}

[1] D. P. B.S. Tselentis, Tourism Carrying Capacity Assessment and Environment: The Case of Crete. Crete, 2011.

[2] S. Budi, "Penataan dan Pengembangan Obyek Wisata Pantai Baron di Kabupaten Gunungkidul," UNDIP, 2009.

[3] R. Damayanti, A., \& Ayuningtyas, "Karakteristik Fisik dan Pemanfaatan Pantai Karst Kabupaten Gunungkidul," Makara Teknol., vol. 12, no. 2, pp. 91-98, 2008.

[4] R. N. Fitrah, "Pengaruh Daya Dukung Kawasan Terhadap Tingkat Kepuasan Wisatawan di Pantai Pangandaran," Univ. Pendidik. Indones., 2011.

[5] R. Grossman, "Carrying Capacity," 2013. [Online]. Available: htttp://www.populationmatters.org. 